Int. J. Dev. Biol. 55: 889-897

doi: $10.1387 / \mathrm{ijdb} .113366 \mathrm{zc}$

\title{
The tumor macroenvironment and systemic regulation of breast cancer progression
}

\author{
ZAFIRA CASTAÑO* KRISTIN TRACY* and SANDRA S. MCALLISTER* \\ Department of Medicine, Hematology Division, Brigham and Women's Hospital, Harvard Medical School, \\ Boston, Massachusetts, USA
}

\begin{abstract}
Breast cancer is the most common malignancy among women worldwide and is the most common cause of death for women between 35 and 50 years of age. Women with breast cancer are at risk of developing metastases for their entire lifetime and, despite local and systemic therapies, approximately $30 \%$ of breast cancer patients will relapse (Jemal et al., 2010). Nearly all breast cancer related deaths are due to metastatic disease, even though metastasis is considered to be an inefficient process. In some cases, tumor cells disseminate from primary sites at an early stage, but remain indolent for protracted periods of time before becoming overt, life-threatening tumors. Little is known about the mechanisms that cause these indolent tumors to grow into malignant disease. Because of this gap in our understanding, we are unable to predict which breast cancer patients are likely to experience disease relapse or develop metastases years after treatment of their primary tumor. A better understanding of the mechanisms and signals involved in the exit of tumor cells from dormancy would not only allow for more accurate selection of patients that would benefit from systemic therapy, but could also lead to the development of more targeted therapies to inhibit the signals that promote disease progression. In this review, we address the systemic, or "macroenvironmental", contribution to tumor initiation and progression and what is known about how a pro-tumorigenic systemic environment is established.
\end{abstract}

KEY WORDS: metastasis, dormancy, systemic instigation, microenvironment

\section{Disseminated tumor cells}

Most deaths from solid tumors are caused by haematogenous spread of cancer cells into distant organs and their subsequent growth to overt metastases. In general, minimal residual disease is defined as the presence of tumor cells, after surgical removal of the primary tumor, that are not detectable by the current routine diagnostic procedures used for tumor staging in cancer patients, but only become apparent after a period of time. A variety of terms are used in the literature to describe metastatic cells in blood and bone marrow. Tumor cells in visceral organs or bone marrow are most often referred to as disseminated tumor cells (DTCs), and those in the peripherial blood are termed circulating tumor cells (CTCs) (Pantel et al., 2008).

The traditional view was that metastaic spread is a late process in malignant progression, in which a single cell of origin within the original clone acquires genetic variability, allowing sequential evolution of a more aggressive subline of cells (Nowell, 1976). This traditional view, often referred to as the clonal evolution of metastasis model, has been supported by studies demonstrating that copy number profiles in breast cancer primary tumours are highly similar to the metastatic tumors analyzed from these patients, suggesting that metastatic cells emerge from an advanced clonal expansion, and not from an earlier intermediate or a subpopulation different from the bulk of the primary tumor (Navin et al., 2011). The opposing view is that dissemination of primary cancer cells to distant sites is often an early event, particularly during breast cancer progression. In fact, tumor cells have been detected in the circulation and bone marrow of patients with the early tumor type ductal carcinoma in situ (Husemann et al., 2008). Molecular genetic analysis revealed that disseminated tumor cells often display genetic alterations that are distinct from the primary tumor (Ding et al., 2010, Husemann

Abbreviations used in this paper: BMC, bone marrow cell; BMDC, bone marrow derived cell; CTC, circulating tumor cell; DTC, disseminated tumor cell; GRN, granulin; OPN, osteopontin.

\footnotetext{
*Address correspondence to: Sandra S. McAllister. Harvard Medical School, Hematology Div., Brigham and Women's Hospital, 5-214 Karp Research Building 1 Blackfan Circle, Boston, MA 02115, USA.Tel: +1-617-355-9059. Fax: +1-617-355-9093. e-mail: smcallister1@ partners.org

\# Note: These authors contributed equally to this work.
}

Final, author-corrected PDF published online: 29 November 2011

ISSN: Online 1696-3547, Print 0214-6282

(C) 2011 UBC Press

Printed in Spain 
et al., 2008, Klein, 2009). These findings suggest that metastatic cells either diverge from the original tumor as new mutations are acquired during their progression or that metastases arise from a small minority of cells within the primary tumor.

Although the early steps of invasion and metastatic spread might be efficient, experimental models and clinical observations indicate that successful metastatic outgrowth, termed colonization, is quite an inefficient process (Luzzi et al., 1998). Studies suggest that $0.01 \%$ of CTCs can ultimately produce a single bone metastasis, and at least 10,000 CTCs are required for the development of a metastatic colony (Panteleakou et al., 2009). In addition, CTCs have been found in disease-free breast cancer patients up to 20 years after successful treatment (Klein, 2009). Thus, the presence of CTCs is a mandatory, but not sufficient, step in the generation of distant metastasis. In these situations, it is not clear why some CTCs/DTCs are able to give rise to metastases and others are not.

\section{Dormancy and indolent cancers}

The length of time required for the development of metastatic disease suggests a period of dormancy before DTCs are able to grow into clinically relevant metastases. The Australian pathologist Rupert Willis originally coined the term "dormant tumor cells" having conducted autopsy studies to analyze the metastatic spread of human cancers. In 1934 he wrote (p. 114):

When long-delayed metastatic tumors appear in a patient in whom there is no local recurrence of the extirpated primary growth, it is clear that the secondary growths must have arisen from tumor-emboli disseminated from the primary growth before its removal. The neoplastic cells must have lain dormant in the tissues in which they were arrested, and their resumption of growth must be attributed to some alteration in the qualities of these tissues or to some release of growthrestraints exercised by them on tumor cells. The nature of these factors is wholly unknown, and it is for future research to explain the remarkably sudden change of behaviourexhibited by the tumors in the cases under discussion (Willis, 1934).

This concept was updated twenty years later by Geoffrey Hadfield, who introduced the idea of a "temporary mitotic arrest" to describe the prolonged latency periods of otherwise fully malignant tumor cells (Hadfield, 1954). Current experimental models have led to the concepts of cellular dormancy and tumor dormancy. The former argues that dormancy can be accounted for by the fact that disseminated tumor cells are in a state of mitotic arrest (Aguirre Ghiso et al., 1999, Aguirre-Ghiso, 2007, Aguirre-Ghiso et al., 2003, Aguirre-Ghiso et al., 2001). Tumor dormancy, on the other hand, describes the situation during which the rate of cell death counterbalances the rate of cell proliferation within a tumor mass (Almog et al., 2006, Naumov et al., 2006). These two general forms of latency are not mutually exclusive; theoretically, both types of dormancy could coexist in the entire DTC population of a particular cancer patient.

While the general connotation of "dormancy" implies reference to metastatic disease, primary tumors can also undergo a period of latency until their clinical diagnosis. For example, women with primary breast cancer often return to the clinic with additional ipsilateral or contralateral primary breast tumors that were not detected at the time of initial diagnosis (Panet-Raymond et al., 2011a, Panet-Raymond et al., 2011b). Moreover, autopsy studies of young men and women with no medical history of cancer uncovered a surprisingly high number of cancers that had been clinically unapparent within the general population (Black and Welch, 1993, Folkman and Kalluri, 2004). An autopsy study of women between the ages of $40-49$ revealed that nearly $40 \%$ of these women had some type of incipient breast tumor, yet only $2 \%$ of all women in this age category are ever diagnosed with breast cancer (Nielsen et al., 1987, Sakr et al., 1995). Similarly, prostate carcinoma in situ was surreptitiously discovered in as many as $31 \%$ of men aged 60-70 years who died of trauma but is clinically diagnosed in only approximately $8 \%$ of men in this age group (Sanchez-Chapado et al., 2003). Most strikingly, microscopic carcinoma (often less than $1 \mathrm{~mm}$ in diameter) was found in the thyroid of more than $38 \%$ of individuals 41 to 60 years of age who died of trauma, but is diagnosed in only $0.5 \%$ of individuals in this age group (Harach et al., 1985). In these cases, cancer dormancy is clearly a protracted stage in tumor progression in which primary tumors remain occult and patients are asymptomatic for a prolonged period of time. It is not known whether primary tumor dormancy is mechanistically different from metastatic dormancy, as the former is defined by controlled or unsuccessful growth within the natural habitat of the transformed cell, while DTCs must adapt to a new microenvironment.

The fact that DTCs must adapt to the environment of the metastatic site may partially explain why metastastic colonization is an inefficient process. A lack of proper growth signals and cell-to-cell signalling attachements was shown to lead to dormancy of DTCs in vivo, suggesting that a foreign microenvironment, with improper cell contacts and signaling, can lead to tumor cell dormancy (Aguirre Ghiso et al., 1999). Conversely, tumor cells that have the ability to establish proper heterotypic interactions in their new environment have been shown in experimental models to form successful metastases (Shibue and Weinberg, 2009). In addition, nascent metastastic outgrowths must obtain a blood supply in order to grow to a significant size. Although cells in a primary tumor may be competent to induce angiogenesis, DTCs that have left the primary site before acquisition of this trait would ostensibly need to acquire intrinsic angiogenic ability or receive help from other sources, such as their microenvironment (Aguirre-Ghiso, 2007, Almog, 2010). Furthermore, surveillance by cells of the immune system can block the expansion and proliferation of DTCs, and thus this immunosurveillance must be evaded for the development of an overt metastasis (Aguirre-Ghiso, 2007, Eyles et al., 2010). Though the challenges facing disseminated tumor cells at a metastatic site have been described, the mechanisms by which tumor cells overcome these challenges are just starting to be elucidated.

\section{Systemic instigation}

A growing body of evidence supports the notion that the tumors that co-exist in a patient who has multiple tumor burden can interact systemically to modulate overall cancer progression (Kim et al., 2009, McAllister and Weinberg, 2010, Mullen et al., 1985, O'Reilly et al., 1997, O'Reilly et al., 1994). Indeed, indolent human breast cancer cells ("responders") that are disseminated to various anatomical locations within host mice can be stimulated to form malignant tumors by systemic factors, namely cytokines and bone marrow-derived cells (McAllister et al., 2008). These systemic signals are provided by aggressively growing human 
breast tumors ("instigators") located at anatomical sites distant from the disseminated responding tumors. Instigating tumors exert their influence on the responding tumors from a distant anatomical location without metastasizing, or "self seeding", to the sites where indolent tumors reside (Kim et al., 2009). Therefore, the process by which one tumor stimulates the distant growth of another is termed "systemic instigation."

The process of systemic instigation is evocative of earlier reports demonstrating that multiple tumors within a mouse host could affect one another from a distance. For instance, multiple tumor burden was shown to enhance the growth of otherwise latent cancers (Mullen et al., 1985); in these studies, the presence of an immune-suppressor tumor growing in one anatomical site enabled the progression of otherwise-weakly tumorigenic foci at distant sites. In some experimental mouse isograft studies, antiangiogenic factors secreted by a subcutaneous tumor inhibit the outgrowth of lung metastases by indirectly increasing apoptosis in tumor cells (Gohongi et al., 1999, Holmgren et al., 1995). On the other hand, it has been described that some tumors release pro-angiogenic factors, which induce mobilization of hematopoietic and endothelial precursor cells from the bone marrow into the circulation to support angiogenesis (Heissig et al., 2002, Moore et al., 2001, Orimo et al., 2005, Rafii, 2000).

Collectively, clinical and experimental findings support the notion that primary tumors prior to their resection or metastatic colonies that have gained a growth advantage after surgical removal of the primary tumor can establish a pro-tumorigenic systemic environment to promote the progression of disseminated micrometastases that are poised to respond to these signals. It is becoming increasingly clear that many aspects of tumor progression can only be explained by a detailed understanding of both paracrine and systemic signaling cascades.

\section{Mediators of systemic instigation}

Implicit in the concept of systemic instigation is the notion that tumor activation of the host systemic environment is separable from response of tumors to the host systemic environment, or "macroenvironment". Establishment of the pro-tumorigenic systemic environment is mediated in part by the cytokine osteopontin (OPN), which is elevated in the plasma of patients with metastatic cancers and predictive of poor outcome (Mor et al., 2005, Rudland et al., 2002, Tuck et al., 2007). OPN is necessary but not sufficient for the instigation process, indicating that other tumor-derived factors are required for the process (McAllister et al., 2008). It is clear that indolent tumor cells are the ultimate beneficiaries of systemic instigation, but the systemic cascade also impinges upon the responding tumor microenvironment, namely tumor stromal cells. Indeed, solid tumors are composed of a multitude of stromal cell types in addition to cancerous cells. Among the stromal cell types that have been implicated in tumor promotion are endothelial cells, which comprise the blood and lymphatic circulatory systems,
INSTIGATING TUMOR

(e.g. primary tumor, metastatic colony with growth advantage)

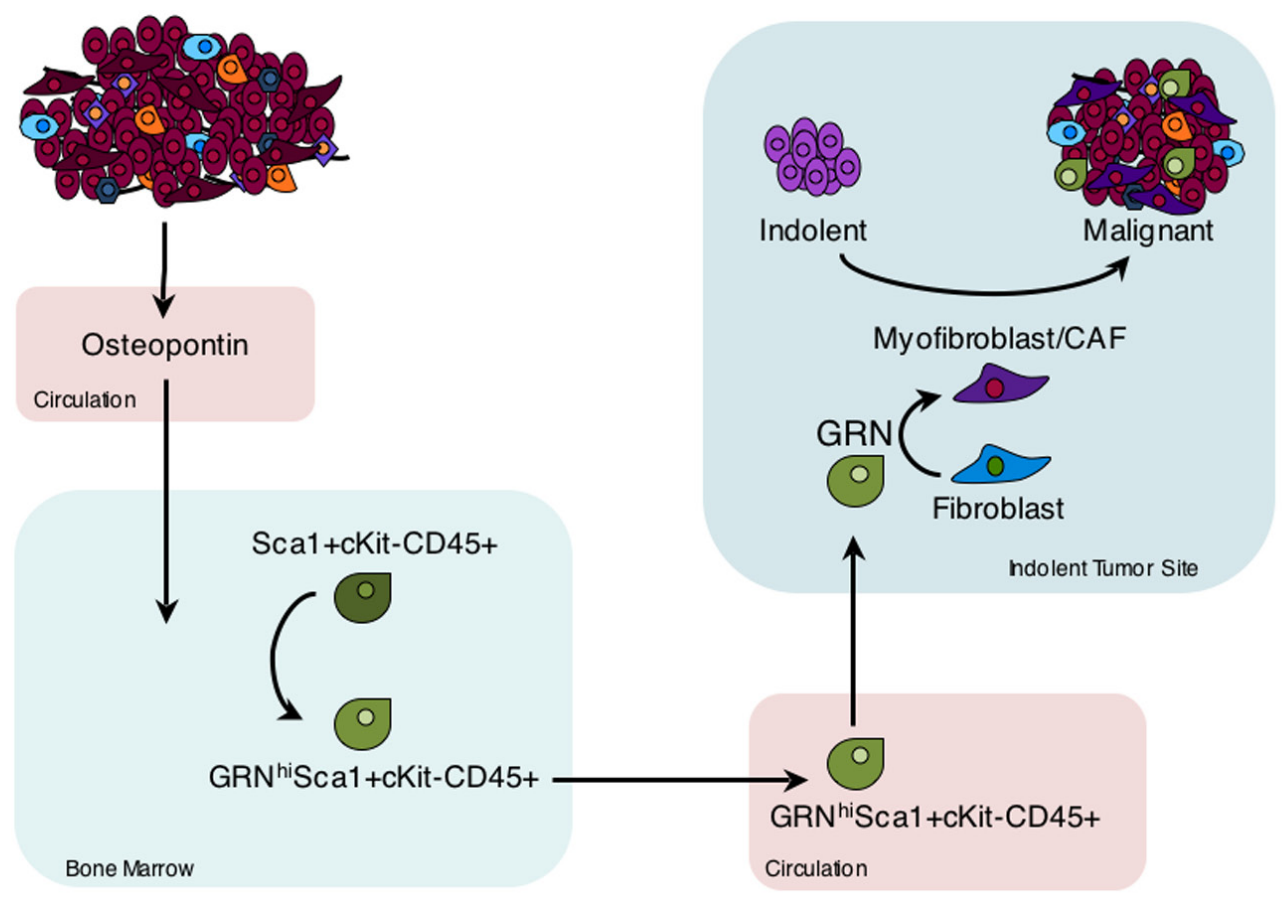

Proliferative tumor cell

Indolent tumor cell

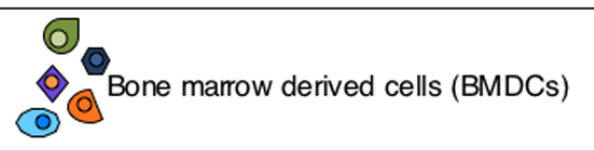

RESPONDING TUMOR

(e.g. second primary neoplasia, indolent metastatic colony) 
pericytes, fibroblasts, and various bone marrow derived cells (BMDCs), such as macrophages, neutrophils, mast cells, myeloid cell-derived suppressor cells, and mesenchymal stem cells (Joyce and Pollard, 2009).

Fibroblasts are primarily responsible for the synthesis, deposition, and remodelling of the extracellular matrix (ECM), as well as for the production of many soluble paracrine growth factors that regulate cell proliferation, morphology, survival, and death. Historically, fibroblasts were thought to be passive participants during neoplastic development; however, several studies indicate that they exert an active role and, in combination with inflammatory cells, can promote neoplastic programming of tissues (Fleming et al., 2010, Martin et al., 2009, Pazolli et al., 2009, Romanov et al., 2001, Tlsty and Coussens, 2006, Wallace et al., 2011). Ultrastructural studies, immunhistochemistry, and biochemical analysis have each contributed to the appreciation that the microenvironment is altered at critical steps during the neoplastic process (RonnovJessen et al., 1996). In tumors, fibroblasts have been referred to as myofibroblasts, peritumoral fibroblasts, reactive stromal cells, and carcinoma-associated fibroblasts (CAFs). They typically exhibit a higher proliferative index compared to fibroblasts in normal tissues, often express $\alpha$-smooth muscle actin ( $\alpha \mathrm{SMA})$, and are commonly surrounded by dense accumulations of fibrillar collagens (Ronnov-Jessen et al., 1996). This phenotype - common in nearly all malignant adenocarcinomas - is termed desmoplasia and is associated with the recruitment of inflammatory cells and activation of angiogenic programs.

The pro-tumorigenic systemic environment also eventually impinges upon the tumor microenvironment. Systemic instigation, at least as defined above, is mediated, in large part, by a subpopulation of Sca-1+/cKit-/CD45+ bone marrow cells (BMCs) that are activated in response to a growing instigating breast tumor (Elkabets et al., 2011). Sca-1+/cKit-cells have been identified as a subpopulation of progenitor cells that can give rise to all hematopoietic lineages, and have even been shown to give rise to the hematopoietic stem cell (Lin-/Sca1+/cKit+) (Harman et al., 2008, Kumar et al., 2008, Randall and Weissman, 1998, Trowbridge et al., 2010, Xiao et al., 2008). In mice bearing instigating tumors, these cells are rendered pro-tumorigenic in the bone marrow prior to their differentiation and mobilization into the circulation, and are induced to express high levels of the secreted glycoprotein granulin (GRN). A member of the epithelin family of growth factors, GRN is expressed by multiple cells types, including hematopoietic cells, epithelial cells, and some neurons. GRN promotes proliferation, migration, and survival and regulates inflammation, and high GRN expression in tumors has been correlated with high-grade lesions (Bateman and Bennett, 2009, Elkabets et al., 2011). Consistent with a potential role for GRN in mediating stromal desmoplasia, GRN is highly expressed in wound tissues and has been demonstrated to increase the numbers of fibroblasts and capillaries that enter wounds in the early stages of healing (He et al., 2003).

Once mobilized, the pro-tumorigenic GRN-expressing Sca-1+/ cKit-/CD45+ BMCs travel to sites where incipient tumors reside. Here, GRN secreted from these BMCs mediates the assembly of a desmoplastic tumor stroma by stimulating fibroblast differentiation. Fibroblasts stimulated with GRN elaborate proteins that define cancer-associated fibroblasts (CAFs), including $\alpha \mathrm{SMA}$ and a host of pro-inflammatory and matrix remodeling cytokines (Elkabets et al., 2011, Erez et al., 2010). These activated CAFs, in turn, support growth of the otherwise indolent tumors (Fig. 1). Such reactive stroma is nearly always observed in malignant adenocarcinomas and is correlated with reduced patient survival (Bissell and Radisky, 2001, Kalluri and Zeisberg, 2006, Walker, 2001). High levels of GRN expression correlate with the most malignant subtypes of breast cancer, namely triple negative (TN) and basal-like breast cancers, and predict reduced survival of breast cancer patients (Elkabets et al., 2011). In fact, GRN expression also negatively correlates with the more differentiated and less invasive luminal breast cancer subtypes.

\section{Clinical relevance of the tumor-supportive systemic environment}

While the process of systemic instigation was discovered in a human tumor xenograft model, clinical data suggests that the mechanisms of instigation identified in the laboratory could be important in human disease as well. Up to $10 \%$ of breast cancer patients present with distant metastases at diagnosis, and surgery to remove the primary tumor improves patient survival (Klein, 2009, Ruiterkamp et al., 2009, Ruiterkamp et al., 2010). Since breast cancer deaths are most often due to metastatic disease rather than the primary tumor (Jemal et al., 2008), the fact that removal of the primary tumor promotes survival of patients with metastases suggests that signals from the primary tumor may contribute to the malignancy of distant metastases. Furthermore, a small percentage of women diagnosed with breast cancer present with synchronous bilateral disease, i.e. tumors in both breasts. Such patients have significantly poorer overall survival compared to those with metachronous bilateral or unilateral tumors (Carmichael et al., 2002). A large study of patients with invasive breast cancer (IBC) found a 2-3 fold increased risk of the development of a tumor in the contralateral breast (Schaapveld et al., 2008), and breast cancer patients also have a high risk of developing a second primary cancer in another organ (Okamoto et al., 1987). While there are many possible explanations for these clinical phenomena, these observations support the notion that signals from a primary breast tumor may promote the growth of an otherwise indolent, undetectable tumor in the contralateral breast or another organ.

In many cases, the timing with which multiple foci of recurrent disease are detected appears to be synchronized. The mathematical likelihood of finding only one lung metastasis as the first recurrent lesion 10 years after breast cancer surgery is statistically higher than finding two or more (Withers and Lee, 2006), but clinical observations and follow up studies show that most breast cancer patients present with two or more lesions at the time of first recurrence (Greenberg et al., 1996, Swenerton et al., 1979, Tomiak et al., 1996, Withers and Lee, 2006). Furthermore, autopsy studies have shown that patients with metastatic cancer have an average of 5.6 metastases in 2-3 organs (Klein, 2009). It is unclear why metastases would appear suddenly and synchronously. Nevertheless, these findings support the idea that there may be a systemic and synchronized instigation-like process in which one metastatic colony that has spontaneously acquired a growth advantage stimulates the growth of incipient disseminated tumor cells or micrometastases at distant sites in the same cancer patient.

Many cancer patients have been found to harbor disseminated cancer cells (DTCs) in their peripheral blood and bone marrow, as well as at common sites of visceral metastasis, such as the liver 
and lungs, even up to 20 years after successful treatment of the primary tumor and in the absence of clinically detectable recurrence (Aguirre-Ghiso, 2007, Fehm et al., 2008, Klein, 2009, Nagrath et al., 2007, Pantel et al., 1999). Since only a subset of these DTCs and pre-malignancies will escape dormancy and become clinically relevant tumors or metastases, an understanding of the signals that mediate escape from dormancy is critical. Future studies along these lines stand to unify the existing experimental theories about early dissemination of metastases and the clinical observations of disease recurrence months or years after surgery and chemotherapy. Appropriate preclinical models will likely be very important tools in the search for factors that contribute to the development of disease relapse as well as for testing therapies aimed at interrupting tumor-supportive systemic processes.

\section{Systemic instigation in mouse xenograft models}

A number of immunocompromised mouse strains have been used for the study of human tumor growth though xenograft implantation, and have yielded an abundance of clinically relevant results (Al-Hajj et al., 2003, Behbod et al., 2009, Bos et al., 2009, Kang et al., 2003, Kim et al., 2009, Minn et al., 2005, Quintana et al., 2010). The Nude mouse is one of the least immunocompromised strains. Nude mice are essentially athymic, and therefore lack mature $\mathrm{T}$ and $\mathrm{B}$ cells. However, they do have normal $\mathrm{B}$ and $\mathrm{T}$ cell precursors in the bone marrow, as well as functional NK cells and macrophages (Clarke, 1996, Liu and Hicklin, 2011). Other mouse strains commonly used for human tumor xenograft studies include SCID, NOD-SCID, and Rag-1 deficient mice. SCID mice lack mature and pre-B and T cells while retaining normal NK cells and macrophages, NOD-SCID mice lack B and T cells, NK cells, and macrophages (Clarke, 1996, Liu and Hicklin, 2011), and Rag1deficient mice lack mature and pre- $\mathrm{B}$ and $\mathrm{T}$ cells (Mombaerts et al., 1992). Interestingly, the systemic instigation process that was identified in Nude mice is significantly less efficient in NOD-SCID and Rag1-deficient mice (unpublished observations).

These observations suggest that a component of the immune system that is functional in Nude mice but not the other immunocompromised strains may be involved in the creation of a tumor-supportive macroenvironment. Indeed, recent studies have highlighted the importance of B and T cells and macrophages in tumor initiation and progression (Andreu et al., 2010, de Visser et al., 2005, DeNardo et al., 2009, Shiao and Coussens, 2010). These elegant studies defined the immune infiltrate in developed tumors, but did not report on the presence of early hematopoietic precursor cells (e.g., homologues of the Sca1+/cKit-/CD45+cells). The systemic instigation model indicates that tumor-supportive BMCs are active prior to their differentiation and mobilization into the circulation and subsequent recruitment into incipient tumors. Future studies of precursor/product relationships and the fate of hematopoietic progenitor cells at the tumor site will likely be very informative.

\section{New era: new instigators?}

The tumor-supportive systemic environment created by certain aggressively growing tumors or metastatic colonies might provide one explanation for the outgrowth of dormant disseminated tumor cells in patients. However, it is possible that other insults induce the outgrowth of otherwise dormant cells. In 1863 Virchow hypothesized that cancer originates at sites of chronic inflammation, in part based on his hypothesis that some classes of irritants, which he called "promoters", enhance cell proliferation due to tissue injury (reviewed by (Balkwill and Mantovani, 2001)). When tissues are wounded or exposed to a chemical irritant, cell proliferation is enhanced to facilitate tissue regeneration or wound healing, thus maintaining homeostasis. Furthermore, it has been shown that individuals suffering from chronic inflammatory disorders harbor a greatly increased risk for cancer development, owing primarily to the pro-growth environment generated by activated inflammatory cells (Tlsty and Coussens, 2006).

Based on this theory, several researchers have analyzed the effects of surgery on patient outcome (Retsky et al., 2008). Evaluation of disease recurrence patterns in more than 1,000 breast cancer patients demonstrated that cancer patients who did not undergo surgery showed a single peak of recurrence approximately 4-5 years following diagnosis (Demicheli et al., 1994). In contrast, a bi-modal pattern, which could not be explained by a continuous tumor growth model, was observed in patients who underwent mastectomy. The recurrence pattern showed an early peak at approximately 18 months after surgery, whereas a second peak of recurrence was documented at approximately 60 months, followed by a plateau-like tail extending up to 15 years (Demicheli et al., 2007). The surgical techniques by which tumors are removed have recently been shown to influence outcome. Indeed, open resection of colorectal cancer was associated with shorter diseasefree interval and time to recurrence compared with laparoscopic resection (Coffey et al., 2003). It has been speculated that these patterns can in part be explained by surgery-driven interruption of dormant micrometastatic breast cancer by a surge of growth factors (Coffey et al., 2003, Demicheli et al., 2007, Retsky et al., 2008).

In agreement with these studies, metastatic models of murine mammary carcinoma indicate that hepatic surgery prior to intravenous injection of tumor cells promoted colonization in the liver of tumor cells that would otherwise not form metastatic colonies (Murthy et al., 1989). Tumor burden was significantly reduced if the injection of cancer cells was delayed relative to surgery, suggesting that the acute and early wound healing processes supported tumor implantation. These findings have been echoed by studies demonstrating that certain bone marrow derived cells help to establish "pre-metastatic" niches (Hiratsuka et al., 2002, Kaplan et al., 2005).

In addition to surgery, wound trauma has been associated with clinical manifestations of recurrent disease (Gamatsi et al., 2000, Kotzen et al., 1999, Morihara et al., 2007, Oosterling et al., 2005). In experimental studies, burn injury resulted in a rapid mobilization of circulating endothelial precursor cells from the bone marrow, ostensibly in response to elevated levels of plasma vascular endothelial growth factor (VEGF) (Gill et al., 2001). Other studies elegantly demonstrated the importance of wound-induced inflammation on the transformation of local epithelial cells (Bissell and Radisky, 2001) (Dolberg et al., 1985, Sieweke et al., 1990). These studies are supported by the fact that carcinomas have been known to arise in post-burn or wound scar tissue in human patients (Bowers and Young, 1960, Horton et al., 1958, Flook et al., 1986).

The contribution of inflammation and inflammatory cells to tumorigenesis and disease progression has been well established. During wound healing or at sites of infection, macrophages secrete 
factors that recruit other circulating cells and have been shown to promote tumor malignancy and modulate response to therapy (DeNardo et al., 2010, Joyce and Pollard, 2009, Wyckoff et al., 2004). Carcinoma cells do not appear to be passive recipients of inflammatory cells. Instead, various carcinomas have been shown to express chemotactic factors, such as colony-stimulating factor 1 (CSF-1) to attract macrophages that express the receptor, CSF-1R (Lin and Pollard, 2007). Macrophages, in turn, promote tumor growth through secretion of growth factors, such as epidermal growth factor (EGF), which signals via the EGF receptor expressed on tumor cells (DeNardo et al., 2011, Wyckoff et al., 2004). Inhibition of this paracrine loop results in suppression of tumor growth and metastasis, indicating that tumor-associated macrophages are essential for tumor progression (Aharinejad et al., 2004, DeNardo et al., 2011, Wyckoff et al., 2004). Another cytokine, the secreted glycoprotein osteopontin (OPN), has attracted considerable attention, as it plays important roles in both wound healing and establishing the tumorsupportive systemic environment (McAllister et al., 2008, Pazolli et al., 2009, Tuck et al., 2007). In addition to these roles, OPN has pro-migratory effects on macrophages, dendritic cells and T cells within the tumor microenvironment (Buback et al., 2009). During wound healing, OPN is involved in granulation tissue formation and scarring and influences fibroblast behavior (Miyazaki et al., 2008, Mori et al., 2008). High expression of OPN also correlates with the appearance of metaplasia after chronic inflammation (Chang et al., 2011). Hence, these various physiological processes might inadvertently establish a pro-tumorigenic systemic environment that would support growth of incipient tumor cells that are poised to respond to them (Fig. 2).

\section{Conclusions and perspectives}

It has been evident for over a century that cancer is a systemic disease, and our interpretation of this concept is continually evolving. The active participation of the complex host macroenvironment in tumor progression is only beginning to be appreciated. Ultimately, the manner in which systemic cascades impinge upon the tumor microenvironment is likely to determine the fate of incipient tumor

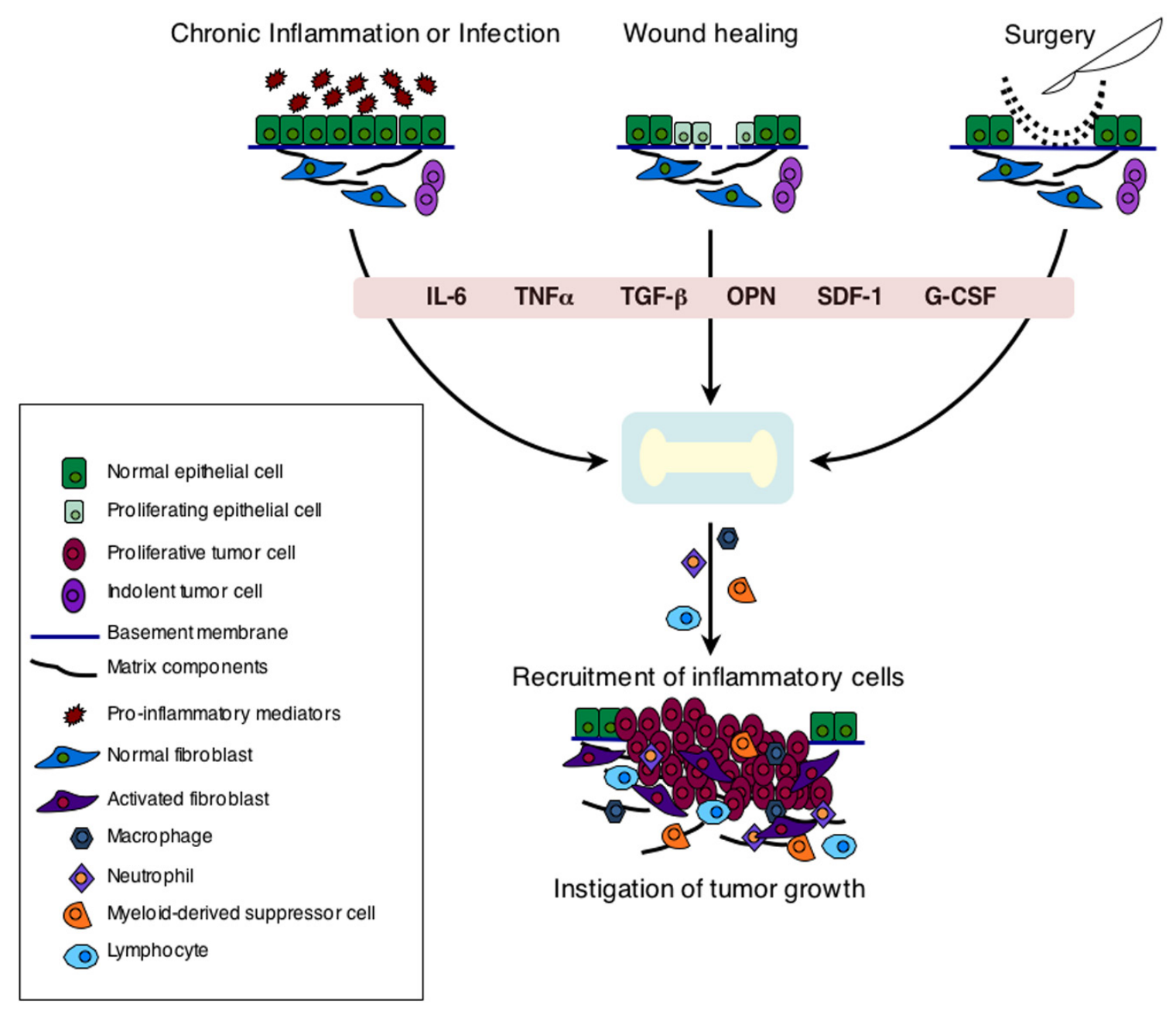

Fig. 2. Pathways that connect chronic inflammation, wound healing, and surgery with cancer. Conditions of chronic inflammation, wound healing, or surgery produce a host of inflammatory mediators (only some of which are indicated), thereby inducing mobilization of bone marrow derived cells into the circulation. These inflammatory cells are recruited to the wounded tissue where they induce activation of fibroblasts into myofibroblasts. These processes serve to create a microenvironment that is conducive to the outgrowth of indolent tumor cells. In this figure we have omitted endothelial cells and the vasculature, obviously important microenvironmental components, as they are not specifically addressed in this review. 
cells. There are many questions that remain unanswered. For example, it remains obscure how pro-tumorigenic BMCs are activated and how they are trafficked from the bone marrow into various tumors. It is not clear what regulates the final differentiation and function of bone marrow derived and stromal cells at sites where tumors or incipient metastases reside. It is also unknown whether there are cellular and molecular components that are common to all types of pro-tumorigenic macroenvironments or whether these are specific to particular tissues and tumor types (Camp et al., 2011).

Several other outstanding issues also require further clarification. For example, despite the diversity of tumor types and transforming events, are there aspects of cancer-related inflammation and/or instigation that are common to all malignancies? Would the blockade of specific pro-tumorigenic BMCs inhibit disease recurrence? Would the neoadjuvant administration of anti-inflammatory or other anti-growth factor drugs lead to a reduction of recurrence? The challenge for the future is to gain sufficient biological insight to reverse or inhibit the tumor-promoting effects of the macroenvironment, while finding ways to promote a tumor-suppressive environment.

\section{References}

AGUIRRE GHISO, J.A., KOVALSKI, K. and OSSOWSKI, L. (1999). Tumor dormancy induced by downregulation of urokinase receptor in human carcinoma involves integrin and MAPK signaling. J Cell Biol 147: 89-104.

AGUIRRE-GHISO, J.A. (2007). Models, mechanisms and clinical evidence for cancer dormancy. Nat Rev Cancer 7: 834-846.

AGUIRRE-GHISO, J.A., ESTRADA, Y., LIU, D. and OSSOWSKI, L. (2003). ERK(MAPK) activity as a determinant of tumor growth and dormancy; regulation by p38(SAPK). Cancer Res 63: 1684-1695.

AGUIRRE-GHISO, J.A., LIU, D., MIGNATTI, A., KOVALSKI, K. and OSSOWSKI, L. (2001). Urokinase receptor and fibronectin regulate the ERK(MAPK) to p38(MAPK) activity ratios that determine carcinoma cell proliferation or dormancy in vivo. $\mathrm{Mol}$ Biol Cell 12: 863-879.

AHARINEJAD, S., PAULUS, P., SIOUD, M., HOFMANN, M., ZINS, K., SCHAFER, R., STANLEY, E.R. and ABRAHAM, D. (2004). Colony-stimulating factor-1 blockade by antisense oligonucleotides and small interfering RNAs suppresses growth of human mammary tumor xenografts in mice. Cancer Res 64: 5378-8534.

AL-HAJJ, M., WICHA, M.S., BENITO-HERNANDEZ, A., MORRISON, S.J. and CLARKE, M.F. (2003). Prospective identification of tumorigenic breast cancer cells. Proc Natl Acad Sci USA 100: 3983-3988.

ALMOG, N. (2010). Molecular mechanisms underlying tumor dormancy. Cancer Lett 294: 139-146.

ALMOG, N., HENKE, V., FLORES, L., HLATKY, L., KUNG, A.L., WRIGHT, R.D., BERGER, R., HUTCHINSON, L., NAUMOV, G.N., BENDER, E. et al., (2006). Prolonged dormancy of human liposarcoma is associated with impaired tumor angiogenesis. FASEB J 20: 947-949.

ANDREU, P., JOHANSSON, M., AFFARA, N.I., PUCCI, F., TAN, T., JUNANKAR, S., KORETS, L., LAM, J., TAWFIK, D., DENARDO, D.G. et al., (2010). FcRgamma activation regulates inflammation-associated squamous carcinogenesis. Cancer Cell 17: 121-134.

BALKWILL, F. and MANTOVANI, A. (2001). Inflammation and cancer: back to Virchow? Lancet 357: 539-545.

BATEMAN, A. and BENNETT, H.P. (2009). The granulin gene family: from cancer to dementia. Bioessays 31: 1245-1254.

BEHBOD, F., KITTRELL, F.S., LAMARCA, H., EDWARDS, D., KERBAWY, S., HEESTAND, J.C., YOUNG, E., MUKHOPADHYAY, P., YEH, H.W., ALLRED, D.C. et al., (2009). An intraductal human-in-mouse transplantation model mimics the subtypes of ductal carcinoma in situ. Breast Cancer Res 11: R66.

BISSELL, M.J. and RADISKY, D. (2001). Putting tumours in context. Nat Rev Cancer 1: $46-54$.

BLACK, W.C. and WELCH, H.G. (1993). Advances in diagnostic imaging and overestimations of disease prevalence and the benefits of therapy. $N$ Engl $J$ Med
328: $1237-1243$.

BOS, P.D., ZHANG, X.H., NADAL, C., SHU, W., GOMIS, R.R., NGUYEN, D.X., MINN, A.J., VAN DE VIJVER, M.J., GERALD, W.L., FOEKENS, J.A. et al., (2009). Genes that mediate breast cancer metastasis to the brain. Nature 459: 1005-1009.

BOWERS, R.F. and YOUNG, J.M. (1960). Carcinoma arising in scars, osteomyelitis, and fistulae. Arch Surg 80: 564-570.

BUBACK, F., RENKL, A.C., SCHULZ, G. and WEISS, J.M. (2009). Osteopontin and the skin: multiple emerging roles in cutaneous biology and pathology. Exp Dermatol 18: 750-759.

CAMP, J.T., ELLOUMI, F., ROMAN-PEREZ, E., REIN, J., STEWART, D.A., HARRELL, J.C., PEROU, C.M. and TROESTER, M.A. (2011). Interactions with fibroblasts are distinct in Basal-like and luminal breast cancers. Mol Cancer Res 9: 3-13.

CARMICHAEL, A.R., BENDALL, S., LOCKERBIE, L., PRESCOTT, R. and BATES, T. (2002). The long-term outcome of synchronous bilateral breast cancer is worse than metachronous or unilateral tumours. Eur J Surg Oncol 28: 388-391.

CHANG, W.L., YANG, H.B., CHENG, H.C., CHUANG, C.H., LU, P.J. and SHEU, B.S. (2011). Increased Gastric Osteopontin Expression by Helicobacter pylori Infection can Correlate with More Severe Gastric Inflammation and Intestinal Metaplasia. Helicobacter 16: 217-224.

CLARKE, R. (1996). Human breast cancer cell line xenografts as models of breast cancer. The immunobiologies of recipient mice and the characteristics of several tumorigenic cell lines. Breast Cancer Res Treat 39: 69-86.

COFFEY, J.C., WANG, J.H., SMITH, M.J., BOUCHIER-HAYES, D., COTTER, T.G. and REDMOND, H.P. (2003). Excisional surgery for cancer cure: therapy at a cost. Lancet Oncol 4: 760-768.

DE VISSER, K.E., KORETS, L.V. and COUSSENS, L.M. (2005). De novo carcinogenesis promoted by chronic inflammation is B lymphocyte dependent. Cancer Cell 7: 411-423.

DEMICHELI, R., RETSKY, M.W., HRUSHESKY, W.J. and BAUM, M. (2007). Tumor dormancy and surgery-driven interruption of dormancy in breast cancer: learning from failures. Nat Clin Pract Oncol 4: 699-710.

DEMICHELI, R., TERENZIANI, M., VALAGUSSA, P., MOLITERNI, A., ZAMBETTI, M. and BONADONNA, G. (1994). Local recurrences following mastectomy: support for the concept of tumor dormancy. J Natl Cancer Inst 86: 45-48.

DENARDO, D.G., ANDREU, P. and COUSSENS, L.M. (2010). Interactions between lymphocytes and myeloid cells regulate pro- versus anti-tumor immunity. Cancer Metastasis Rev 29: 309-316

DENARDO, D.G., BARRETO, J.B., ANDREU, P., VASQUEZ, L., TAWFIK, D., KOLHATKAR, N. and COUSSENS, L.M. (2009). CD4(+) T cells regulate pulmonary metastasis of mammary carcinomas by enhancing protumor properties of macrophages. Cancer Cell 16: 91-102.

DENARDO, D.G., BRENNAN, D.J., REXHEPAJ, E., RUFFELL, B., SHIAO, S.L., MADDEN, S.F., GALLAGHER, W.M., WADHWANI, N., KEIL, S.D., JUNAID, S.A. et al., (2011). Leukocyte Complexity Predicts Breast Cancer Survival and Functionally Regulates Response to Chemotherapy. Cancer Discovery 1: 54-67.

DING, L., ELLIS, M.J., LI, S., LARSON, D.E., CHEN, K., WALLIS, J.W., HARRIS, C.C. MCLELLAN, M.D., FULTON, R.S., FULTON, L.L. et al., (2010). Genome remodelling in a basal-like breast cancer metastasis and xenograft. Nature 464: 999-1005.

DOLBERG, D.S., HOLLINGSWORTH, R., HERTLE, M. and BISSELL, M.J. (1985). Wounding and its role in RSV-mediated tumor formation. Science 230: 676-678.

ELKABETS, M., GIFFORD, A.M., SCHEEL, C., NILSSON, B., REINHARDT, F., BRAY, M.A., CARPENTER, A.E., JIRSTROM, K., MAGNUSSON, K., EBERT, B.L. et al., (2011). Human tumors instigate granulin-expressing hematopoietic cells that promote malignancy by activating stromal fibroblasts in mice. $J$ Clin Invest 121: 784-799.

EREZ, N., TRUITT, M., OLSON, P., ARRON, S.T. and HANAHAN, D. (2010), Cancer-Associated Fibroblasts Are Activated in Incipient Neoplasia to Orchestrate Tumor-Promoting Inflammation in an NF-kappaB-Dependent Manner. Cancer Cell 17: 135-147.

EYLES, J., PUAUX, A.L., WANG, X., TOH, B., PRAKASH, C., HONG, M., TAN, T.G. ZHENG, L., ONG, L.C., JIN, Y. et al., (2010). Tumor cells disseminate early, but immunosurveillance limits metastatic outgrowth, in a mouse model of melanoma. J Clin Invest 120: 2030-2039.

FEHM, T., MUELLER, V., MARCHES, R., KLEIN, G., GUECKEL, B., NEUBAUER, H., SOLOMAYER, E. and BECKER, S. (2008). Tumor cell dormancy: implications for the biology and treatment of breast cancer. APMIS 116: 742-753. 
FLEMING, J.M., MILLER, T.C., QUINONES, M., XIAO, Z., XU, X., MEYER, M.J., GINSBURG, E., VEENSTRA, T.D. and VONDERHAAR, B.K. (2010). The normal breast microenvironment of premenopausal women differentially influences the behavior of breast cancer cells in vitro and in vivo. BMC Med 8: 27.

FLOOK, D., HORGAN, K., TAYLOR, B.A. and HUGHES, L.E. (1986). Surgery for malignant melanoma: from which limb should the graft be taken? Br J Surg 73: 793-795.

FOLKMAN, J. and KALLURI, R. (2004). Cancer without disease. Nature 427: 787.

GAMATSI, I.E., MCCULLOCH, T.A., BAILIE, F.B. and SRINIVASAN, J.R. (2000). Malignant melanoma in a skin graft: burn scar neoplasm or a transferred melanoma? Br J Plast Surg 53: 342-344.

GILL, M., DIAS, S., HATTORI, K., RIVERA, M.L., HICKLIN, D., WITTE, L., GIRARDI, L., YURT, R., HIMEL, H. and RAFII, S. (2001). Vascular trauma induces rapid but transient mobilization of VEGFR2(+)AC133(+) endothelial precursor cells. Circ Res 88: 167-174.

GOHONGI, T., FUKUMURA, D., BOUCHER, Y., YUN, C.O., SOFF, G.A., COMPTON, C., TODOROKI, T. and JAIN, R.K. (1999). Tumor-host interactions in the gallbladder suppress distal angiogenesis and tumor growth: involvement of transforming growth factor beta1. Nat Med 5: 1203-8.

GREENBERG, P.A., HORTOBAGYI, G.N., SMITH, T.L., ZIEGLER, L.D., FRYE, D.K. and BUZDAR, A.U. (1996). Long-term follow-up of patients with complete remission following combination chemotherapy for metastatic breast cancer. $J$ Clin Oncol 14: 2197-205.

HADFIELD, G. (1954). The dormant cancer cell. Br Med J 2: 607-610.

HARACH, H.R., FRANSSILA, K.O. and WASENIUS, V.M. (1985). Occult papillary carcinoma of the thyroid. A "normal" finding in Finland. A systematic autopsy study. Cancer 56: 531-538.

HARMAN, B.C., NORTHRUP, D.L. and ALLMAN, D. (2008). Resolution of unique Sca-1 highc-Kit- Iymphoid-biased progenitors in adult bone marrow. J Immunol 181: 7514-7524.

HE, Z., ONG, C.H., HALPER, J. and BATEMAN, A. (2003). Progranulin is a mediator of the wound response. Nat Med 9: 225-229.

HEISSIG, B., HATTORI, K., DIAS, S., FRIEDRICH, M., FERRIS, B., HACKETT, N.R., CRYSTAL, R.G., BESMER, P., LYDEN, D., MOORE, M.A. et al., (2002). Recruitment of stem and progenitor cells from the bone marrow niche requires MMP-9 mediated release of kit-ligand. Cell 109: 625-637.

HIRATSUKA, S., NAKAMURA, K., IWAI, S., MURAKAMI, M., ITOH, T., KIJIMA, H., SHIPLEY, J.M., SENIOR, R.M. and SHIBUYA, M. (2002). MMP9 induction by vascular endothelial growth factor receptor-1 is involved in lung-specific metastasis. Cancer Cell 2: 289-300.

HOLMGREN, L., O'REILLY, M.S. and FOLKMAN, J. (1995). Dormancy of micrometastases: balanced proliferation and apoptosis in the presence of angiogenesis suppression. Nat Med 1: 149-153.

HORTON, C.E., CRAWFORD, H.H., LOVE, H.G. and LOEFFLER, R.A. (1958). The malignant potential of burn scar. Plast Reconstr Surg Transplant Bull 22: 348-353.

HUSEMANN, Y., GEIGL, J.B., SCHUBERT, F., MUSIANI, P., MEYER, M., BURGHART, E., FORNI, G., EILS, R., FEHM, T., RIETHMULLER, G. et al., (2008). Systemic spread is an early step in breast cancer. Cancer Cell 13: 58-68.

JEMAL, A., SIEGEL, R., WARD, E., HAO, Y., XU, J., MURRAY, T. and THUN, M.J. (2008). Cancer statistics, 2008. CA Cancer J Clin 58: 71-96.

JEMAL, A., SIEGEL, R., XU, J. and WARD, E. (2010). Cancer statistics, 2010. CA Cancer J Clin 60: 277-300.

JOYCE, J.A. and POLLARD, J.W. (2009). Microenvironmental regulation of metastasis. Nat Rev Cancer 9: 239-252.

KALLURI, R. and ZEISBERG, M. (2006). Fibroblasts in cancer. Nat Rev Cancer 6: 392-401.

KANG, Y., SIEGEL, P.M., SHU, W., DROBNJAK, M., KAKONEN, S.M., CORDONCARDO, C., GUISE, T.A. and MASSAGUE, J. (2003). A multigenic program mediating breast cancer metastasis to bone. Cancer Cell 3: 537-549.

KAPLAN, R.N., RIBA, R.D., ZACHAROULIS, S., BRAMLEY, A.H., VINCENT, L., COSTA, C., MACDONALD, D.D., JIN, D.K., SHIDO, K., KERNS, S.A. et al., (2005). VEGFR1-positive haematopoietic bone marrow progenitors initiate the pre-metastatic niche. Nature 438: 820-827.

KIM, M.Y., OSKARSSON, T., ACHARYYA, S., NGUYEN, D.X., ZHANG, X.H., NORTON, L. and MASSAGUE, J. (2009). Tumor self-seeding by circulating cancer cells. Cell 139: 1315-1326

KLEIN, C.A. (2009). Parallel progression of primary tumours and metastases. Nat Rev Cancer 9: 302-312.

KOTZEN, R.M., SWANSON, R.M., MILHORAT, T.H. and BOOCKVAR, J.A. (1999). Post-traumatic meningioma: case report and historical perspective. $J$ Neurol Neurosurg Psychiatry 66: 796-798.

KUMAR, R., FOSSATI, V., ISRAEL, M. and SNOECK, H.W. (2008). Lin-Sca1+kit-bone marrow cells contain early lymphoid-committed precursors that are distinct from common lymphoid progenitors. J Immunol 181: 7507-7513.

LIN, E.Y. and POLLARD, J.W. (2007). Tumor-associated macrophages press the angiogenic switch in breast cancer. Cancer Res 67: 5064-5066.

LIU, M. and HICKLIN, D. (2011). Human Tumor Xenograft Efficacy Models. In Tumor Models in Cancer Research, (ed. TEICHER, B. A.). Springer Science+Business Media, New York, pp. 99-124.

LUZZI, K.J., MACDONALD, I.C., SCHMIDT, E.E., KERKVLIET, N., MORRIS, V.L., CHAMBERS, A.F. and GROOM, A.C. (1998). Multistep nature of metastatic inefficiency: dormancy of solitary cells after successful extravasation and limited survival of early micrometastases. Am J Pathol 153: 865-873.

MARTIN, D.N., BOERSMA, B.J., YI, M., REIMERS, M., HOWE, T.M., YFANTIS, H.G., TSAI, Y.C., WILLIAMS, E.H., LEE, D.H., STEPHENS, R.M. et al., (2009). Differences in the tumor microenvironment between African-American and EuropeanAmerican breast cancer patients. PLoS One 4: e4531.

MCALLISTER, S.S., GIFFORD, A.M., GREINER, A.L., KELLEHER, S.P., SAELZLER, M.P., INCE, T.A., REINHARDT, F., HARRIS, L.N., HYLANDER, B.L., REPASKY E.A. et al., (2008). Systemic endocrine instigation of indolent tumor growth requires osteopontin. Cell 133: 994-1005

MCALLISTER, S.S. and WEINBERG, R.A. (2010). Tumor-host interactions: a farreaching relationship. J Clin Oncol 28: 4022-4028.

MINN, A.J., GUPTA, G.P., SIEGEL, P.M., BOS, P.D., SHU, W., GIRI, D.D., VIALE, A., OLSHEN, A.B., GERALD, W.L. and MASSAGUE, J. (2005). Genes that mediate breast cancer metastasis to lung. Nature 436: 518-524.

MIYAZAKI, K., OKADA, Y., YAMANAKA, O., KITANO, A., IKEDA, K., KON, S., UEDE, T., RITTLING, S.R., DENHARDT, D.T., KAO, W.W. et al., (2008). Corneal wound healing in an osteopontin-deficient mouse. Invest Ophthalmol Vis Sci49: 1367-1375.

MOMBAERTS, P., IACOMINI, J., JOHNSON, R.S., HERRUP, K., TONEGAWA, S. and PAPAIOANNOU, V.E. (1992). RAG-1-deficient mice have no mature $B$ and T lymphocytes. Cell 68: 869-877.

MOORE, M.A., HATTORI, K., HEISSIG, B., SHIEH, J.H., DIAS, S., CRYSTAL, R.G. and RAFII, S. (2001). Mobilization of endothelial and hematopoietic stem and progenitor cells by adenovector-mediated elevation of serum levels of SDF-1, VEGF, and angiopoietin-1. Ann N Y Acad Sci 938: 36-45; discussion 45-47.

MOR, G., VISINTIN, I., LAI, Y., ZHAO, H., SCHWARTZ, P., RUTHERFORD, T., YUE, L., BRAY-WARD, P. and WARD, D.C. (2005). Serum protein markers for early detection of ovarian cancer. Proc Natl Acad Sci USA 102: 7677-7682.

MORI, R., SHAW, T.J. and MARTIN, P. (2008). Molecular mechanisms linking wound inflammation and fibrosis: knockdown of osteopontin leads to rapid repair and reduced scarring. J Exp Med 205: 43-51.

MORIHARA, K., TAKENAKA, H., MORIHARA, T. and KISHIMOTO, S. (2007). Primary cutaneous anaplastic large cell lymphoma associated with vascular endothelia growth factor arising from a burn scar. J Am Acad Dermatol 57: S103-S105.

MULLEN, C.A., URBAN, J.L., VAN WAES, C., ROWLEY, D.A. and SCHREIBER, H. (1985). Multiple cancers. Tumor burden permits the outgrowth of other cancers. J Exp Med 162: 1665-1682.

MURTHY, S.M., GOLDSCHMIDT, R.A., RAO, L.N., AMMIRATI, M., BUCHMANN, T. and SCANLON, E.F. (1989). The influence of surgical trauma on experimental metastasis. Cancer 64: 2035-2044

NAGRATH, S., SEQUIST, L.V., MAHESWARAN, S., BELL, D.W., IRIMIA, D., ULKUS L., SMITH, M.R., KWAK, E.L., DIGUMARTHY, S., MUZIKANSKY, A. et al., (2007). Isolation of rare circulating tumour cells in cancer patients by microchip technology. Nature 450: 1235-1239.

NAUMOV, G.N., BENDER, E., ZURAKOWSKI, D., KANG, S.Y., SAMPSON, D. FLYNN, E., WATNICK, R.S., STRAUME, O., AKSLEN, L.A., FOLKMAN, J. et al., (2006). A model of human tumor dormancy: an angiogenic switch from the nonangiogenic phenotype. J Natl Cancer Inst 98: 316-325.

NAVIN, N., KENDALL, J., TROGE, J., ANDREWS, P., RODGERS, L., MCINDOO, J., COOK, K., STEPANSKY, A., LEVY, D., ESPOSITO, D. et al., (2011). Tumour 
evolution inferred by single-cell sequencing. Nature 472: 90-94.

NIELSEN, M., THOMSEN, J.L., PRIMDAHL, S., DYREBORG, U. and ANDERSEN, J.A. (1987). Breast cancer and atypia among young and middle-aged women: a study of 110 medicolegal autopsies. Br J Cancer 56: 814-819.

NOWELL, P.C. (1976). The clonal evolution of tumor cell populations. Science 194: 23-28.

O'REILLY, M.S., BOEHM, T., SHING, Y., FUKAI, N., VASIOS, G., LANE, W.S., FLYNN, E., BIRKHEAD, J.R., OLSEN, B.R. and FOLKMAN, J. (1997). Endostatin: an endogenous inhibitor of angiogenesis and tumor growth. Cell 88: 277-285.

O'REILLY, M.S., HOLMGREN, L., SHING, Y., CHEN, C., ROSENTHAL, R.A., MOSES, M., LANE, W.S., CAO, Y., SAGE, E.H. and FOLKMAN, J. (1994). Angiostatin: a novel angiogenesis inhibitor that mediates the suppression of metastases by a Lewis lung carcinoma. Cell 79: 315-328.

OKAMOTO, N., MORIO, S., INOUE, R. and AKIYAMA, K. (1987). The risk of a second primary cancer occurring in five-year survivors of an initial cancer. Jpn $J$ Clin Oncol 17: 205-213.

OOSTERLING, S.J., VAN DER BIJ, G.J., VAN EGMOND, M. and VAN DER SIJP, J.R. (2005). Surgical trauma and peritoneal recurrence of colorectal carcinoma. Eur J Surg Oncol 31: 29-37.

ORIMO, A., GUPTA, P.B., SGROI, D.C., ARENZANA-SEISDEDOS, F., DELAUNAY, T., NAEEM, R., CAREY, V.J., RICHARDSON, A.L. and WEINBERG, R.A. (2005). Stromal fibroblasts present in invasive human breast carcinomas promote tumor growth and angiogenesis through elevated SDF-1/CXCL12 secretion. Cell 121: 335-348.

PANET-RAYMOND, V., TRUONG, P.T., ALEXANDER, C., LESPERANCE, M., MCDONALD, R.E. and WATSON, P.H. (2011a). Clinicopathologic factors of the recurrent tumor predict outcome in patients with ipsilateral breast tumor recurrence. Cancer 117: 2035-2043.

PANET-RAYMOND, V., TRUONG, P.T., MCDONALD, R.E., ALEXANDER, C., ROSS, L., RYHORCHUK, A. and WATSON, P.H. (2011b). True Recurrence versus New Primary: An Analysis of Ipsilateral Breast Tumor Recurrences After BreastConserving Therapy. Int J Radiat Oncol Biol Phys. 81: 409-417.

PANTEL, K., BRAKENHOFF, R.H. and BRANDT, B. (2008). Detection, clinical relevance and specific biological properties of disseminating tumour cells. Nat Rev Cancer 8: 329-340.

PANTEL, K., COTE, R.J. and FODSTAD, O. (1999). Detection and clinical importance of micrometastatic disease. J Natl Cancer Inst 91: 1113-1124.

PANTELEAKOU, Z., LEMBESSIS, P., SOURLA, A., PISSIMISSIS, N., POLYZOS, A., DELIVELIOTIS, C. and KOUTSILIERIS, M. (2009). Detection of circulating tumor cells in prostate cancer patients: methodological pitfalls and clinical relevance. Mol Med 15: 101-114.

PAZOLLI, E., LUO, X., BREHM, S., CARBERY, K., CHUNG, J.J., PRIOR, J.L., DOHERTY, J., DEMEHRI, S., SALAVAGGIONE, L., PIWNICA-WORMS, D. et al., (2009). Senescent stromal-derived osteopontin promotes preneoplastic cell growth. Cancer Res 69: 1230-1239.

QUINTANA, E., SHACKLETON, M., FOSTER, H.R., FULLEN, D.R., SABEL, M.S., JOHNSON, T.M. and MORRISON, S.J. (2010). Phenotypic heterogeneity among tumorigenic melanoma cells from patients that is reversible and not hierarchically organized. Cancer Cell 18: 510-523.

RAFII, S. (2000). Circulating endothelial precursors: mystery, reality, and promise. $J$ Clin Invest 105: 17-19.

RANDALL, T.D. and WEISSMAN, I.L. (1998). Characterization of a population of cells in the bone marrow that phenotypically mimics hematopoietic stem cells: resting stem cells or mystery population? Stem Cells 16: 38-48.

RETSKY, M.W., DEMICHELI, R., HRUSHESKY, W.J., BAUM, M. and GUKAS, I.D. (2008). Dormancy and surgery-driven escape from dormancy help explain some clinical features of breast cancer. APMIS 116: 730-741.

ROMANOV, S.R., KOZAKIEWICZ, B.K., HOLST, C.R., STAMPFER, M.R., HAUPT, L.M. and TLSTY, T.D. (2001). Normal human mammary epithelial cells spontaneously escape senescence and acquire genomic changes. Nature 409: 633-637.

RONNOV-JESSEN, L., PETERSEN, O.W. and BISSELL, M.J. (1996). Cellularchanges involved in conversion of normal to malignant breast: importance of the stromal reaction. Physiol Rev 76: 69-125.
RUDLAND, P.S., PLATT-HIGGINS, A., EL-TANANI, M., DE SILVA RUDLAND, S. BARRACLOUGH, R., WINSTANLEY, J.H., HOWITT, R. and WEST, C.R. (2002). Prognostic significance of the metastasis-associated protein osteopontin in human breast cancer. Cancer Res 62: 3417-3427.

RUITERKAMP, J., ERNST, M.F., VAN DE POLL-FRANSE, L.V., BOSSCHA, K., TJAN-HEIJNEN, V.C. and VOOGD, A.C. (2009). Surgical resection of the primary tumour is associated with improved survival in patients with distant metastatic breast cancer at diagnosis. Eur J Surg Oncol 35: 1146-1151.

RUITERKAMP, J., VOOGD, A.C., BOSSCHA, K., TJAN-HEIJNEN, V.C. and ERNST, M.F. (2010). Impact of breast surgery on survival in patients with distant metastases at initial presentation: a systematic review of the literature. Breast Cancer Res Treat 120: 9-16.

SAKR, W.A., GRIGNON, D.J., HAAS, G.P., SCHOMER, K.L., HEILBRUN, L.K., CASSIN, B.J., POWELL, J., MONTIE, J.A., PONTES, J.E. and CRISSMAN, J.D. (1995). Epidemiology of high grade prostatic intraepithelial neoplasia. Pathol Res Pract 191: 838-841.

SANCHEZ-CHAPADO, M., OLMEDILLA, G., CABEZA, M., DONAT, E. and RUIZ, A. (2003). Prevalence of prostate cancer and prostatic intraepithelial neoplasia in Caucasian Mediterranean males: an autopsy study. Prostate 54: 238-247.

SCHAAPVELD, M., VISSER, O., LOUWMAN, M.J., DE VRIES, E.G., WILLEMSE, P.H., OTTER, R., VAN DER GRAAF, W.T., COEBERGH, J.W. and VAN LEEUWEN, F.E. (2008). Risk of new primary nonbreast cancers after breast cancer treatment: a Dutch population-based study. J Clin Oncol 26: 1239-1246.

SHIAO, S.L. and COUSSENS, L.M. (2010). The tumor-immune microenvironment and response to radiation therapy. J Mammary Gland Biol Neoplasia 15: 411-421.

SHIBUE, T. and WEINBERG, R.A. (2009). Integrin beta1-focal adhesion kinase signaling directs the proliferation of metastatic cancer cells disseminated in the lungs. Proc Natl Acad Sci USA 106: 10290-10295.

SIEWEKE, M.H., THOMPSON, N.L., SPORN, M.B. and BISSELL, M.J. (1990) Mediation of wound-related Rous sarcoma virus tumorigenesis by TGF-beta. Science 248: 1656-1660.

SWENERTON, K.D., LEGHA, S.S., SMITH, T., HORTOBAGYI, G.N., GEHAN, E.A., YAP, H.Y., GUTTERMAN, J.U. and BLUMENSCHEIN, G.R. (1979). Prognostic factors in metastatic breast cancer treated with combination chemotherapy. Cancer Res 39: 1552-1562.

TLSTY, T.D. and COUSSENS, L.M. (2006). Tumor stroma and regulation of cancer development. Annu Rev Pathol 1: 119-150.

TOMIAK, E., PICCART, M., MIGNOLET, F., SAHMOUD, T., PARIDAENS, R., NOOY M., BEEX, L., FENTIMAN, I.S., MULLER, A., VAN DER SCHUEREN, E. et al., (1996). Characterisation of complete responders to combination chemotherapy for advanced breast cancer: a retrospective EORTC Breast Group study. Eur J Cancer 32A: 1876-1887.

TROWBRIDGE, J.J., GUEZGUEZ, B., MOON, R.T. and BHATIA, M. (2010). Wnt3a activates dormant C-Kit(-) bone marrow-derived cells with short-term multilineage hematopoietic reconstitution capacity. Stem Cells 28: 1379-1389.

TUCK, A.B., CHAMBERS, A.F. and ALLAN, A.L. (2007). Osteopontin overexpression in breast cancer: knowledge gained and possible implications for clinical management. J Cell Biochem 102: 859-868.

WALKER, R.A. (2001). The complexities of breast cancer desmoplasia. Breast Cancer Res 3: 143-145.

WALLACE, J.A., LI, F., LEONE, G. and OSTROWSKI, M.C. (2011). Pten in the breast tumor microenvironment: modeling tumor-stroma coevolution. Cancer Res 71: 1203-1207.

WILLIS, R.A. (1934). The Spread of Tumors in the Human Body. J. \& A. Churchill, London.

WITHERS, H.R. and LEE, S.P. (2006). Modeling growth kinetics and statistical distribution of oligometastases. Semin Radiat Oncol 16: 111-119.

WYCKOFF, J., WANG, W., LIN, E.Y., WANG, Y., PIXLEY, F., STANLEY, E.R., GRAF, T., POLLARD, J.W., SEGALL, J. and CONDEELIS, J. (2004). A paracrine loop between tumor cells and macrophages is required for tumor cell migration in mammary tumors. Cancer Res 64: 7022-7029.

XIAO, S., SU, D.M. and MANLEY, N.R. (2008). T cell development from kit-negative progenitors in the Foxn1Delta/Delta mutant thymus. J Immunol 180: 914-921. 


\section{Further Related Reading, published previously in the Int. J. Dev. Biol.}

Epithelial-Mesenchymal Transitions in development and disease: old views and new perspectives.

M. Angela Nieto

Int. J. Dev. Biol. (2009) 53: 1541-1547

Reprogramming of melanoma cells by embryonic microenvironments.

Alejandro Díez-Torre, Ricardo Andrade, Cristina Eguizábal, Elixabete López, Jon Arluzea, Margarita Silió and Juan Aréchaga Int. J. Dev. Biol. (2009) 53: 1563-1568

The countercurrent principle in invasion and metastasis of cancer cells. Recent insights on the roles of chemokines.

Opdenakker G, Van Damme J.

Int J Dev Biol. (2004) 48: 519-27

The chemokine network in cancer--much more than directing cell movement.

Kulbe H, Levinson NR, Balkwill F, Wilson JL.

Int J Dev Biol. (2004) 48: 489-96

Molecular aspects of cancer metastasis: extracellular regulation of the E-cadherin/catenin complex.

M Mareel, T Boterberg, V Noë, E Bruyneel and M Bracke

Int. J. Dev. Biol. (1996) 40: S65-S67

$$
5 \text { yr ISI Impact Factor }(2010)=2.961
$$

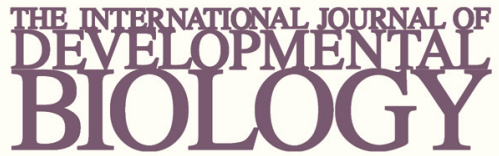

Volume 54 Nos. 6/7

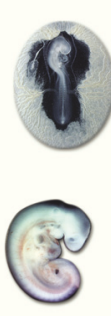

$\Rightarrow$
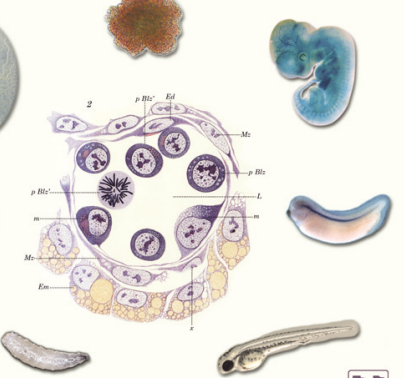

Developmental Hematopoiesis

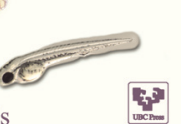

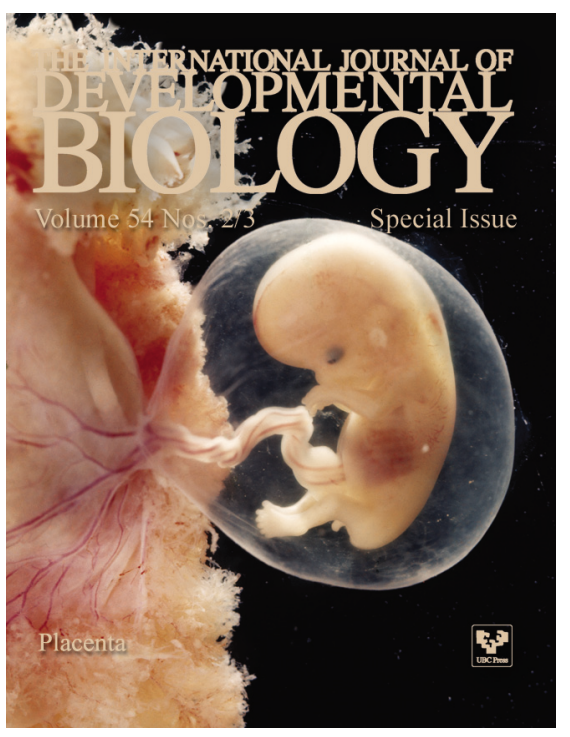

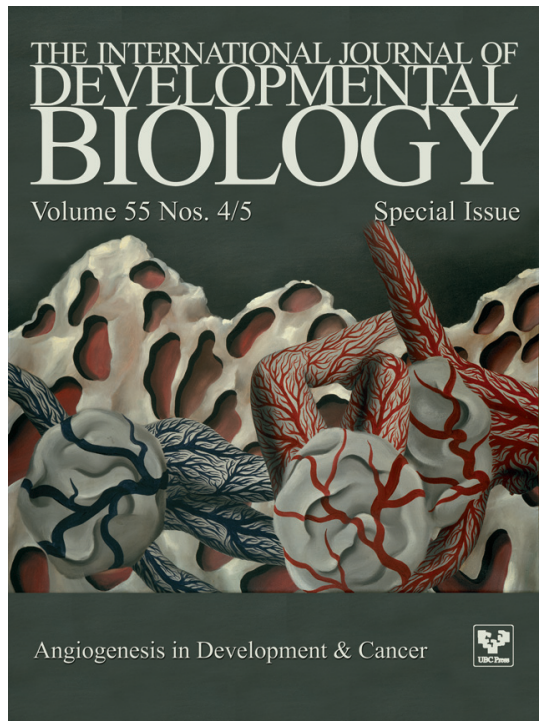

